\title{
Climate Change: Vulnerability Assessment of Vanishing Springs in the Mid-Hills of Nepal
}

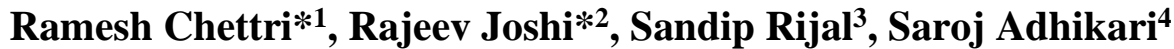 \\ ${ }^{1}$ Kali Gandaki polytechnic Institute, CTEVT, Ghiring 1, Tanahun-33900, Nepal \\ ${ }^{2}$ Programme Coordinator (Forestry), Amity Global Education (Lord Buddha College), CTEVT, Tokha -11, \\ Kathmandu-44600, Nepal \\ ${ }^{3}$ Forest Research Institute (Deemed to be University), Dehradun-248195, Uttarakhand, India \\ ${ }^{4}$ Department of Botany, Tribhuwan University, Kathmandu-44600, Nepal \\ *Corresponding author ${ }^{l}$ : rameshchhetri155@gmail.com |ORCID: 0000-0003-2226-9468 \\ *Corresponding author ${ }^{2}$ : joshi.rajeev20@ gmail.com | ORCID: 0000-0003-1106-9911
}

How to cite this paper: Chettri, R., Joshi, R., Rijal, S. and Adhikari, S. (2020). Climate Change: Vulnerability Assessment of Vanishing Springs in the Mid-Hills of Nepal. Grassroots Journal of Natural Resources, 3(3): 1-15. Doi:

https://doi.org/10.33002/nr2581.6853.03031

Received: 11 June 2020

Reviewed: 30 June 2020

Provisionally Accepted:13July 2020

Revised: 25 July 2020

Finally Accepted: 17 August 2020

Published:15 September 2020

Copyright $@ 2020$ by author(s)

This work is licensed under the Creative Commons Attribution International License (CC BY 4.0).

http://creativecommons.org/licenses/by/4.0/

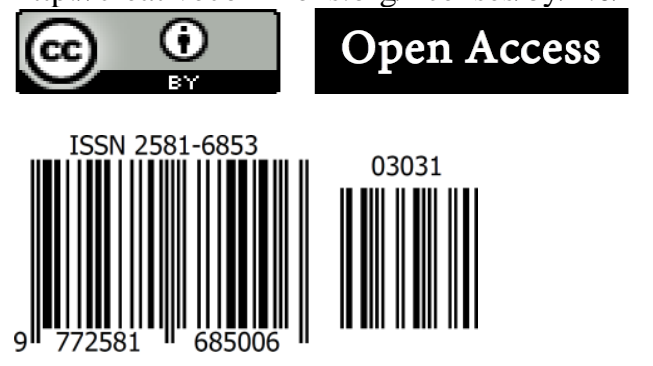

\begin{abstract}
Springs are the major source of water supply for domestic and agricultural uses in the mid-hills of Nepal. Therefore, these resources must be preserved and protected for the benefit of the ecology, environment, economic wellbeing and quality of life. This study aimed to assess the community perception and vulnerability assessment of spring water. Based on the participatory methods, views and experiences of communities were analyzed to understand their perception towards climate change. On the other hand, vulnerability assessment was carried out to analyze the situation of water availability in springs. The study reveals that water consumer communities have experienced changing patterns of local climate which correlates with the long-term rainfall and temperature data. Vulnerability ranged from 0.10 to 0.67 . Moreover, meager water resources and low discharge during summer have resulted a lot of hardship to the people. The findings will assist policymakers and development agencies to plan and implement their projects more effectively at the local and national levels.
\end{abstract}

\section{Keywords}

Indices, Springs, Vulnerability, Wards, Water resource 
Doi: https://doi.org/10.33002/nr2581.6853.03031

\section{Introduction}

Climate change is one of the key challenges for human population, and the most serious threat to the sustainability of development. Adverse effects of the climate change are visible on human health, food security, and socio-economic activity (Salem et al., 2019). Roughly about one-quarter of the world population, nearly 1.7 billion people, live in countries experiencing water stress (Watson, 2001). When water resource is sensitive to climate change (Chaulagain, 2009; Chhetri and Kumar, 2018), pressure of non-climatic factors such as population increase, rapid economic development, and land-use changes will further aggravate the impacts of climate change on fresh water resources (Kundzewicz et al., 2007; Stathatou et al., 2016; Chhetri et al., 2020). Hence, water resource planning and management is becoming an increasingly difficult task in the $21^{\text {st }}$ century (Raneesh, 2014).

Addressing the issues of water resource management is reflected in the growing use of terminologies, such as 'virtual water', 'water as blue gold', 'water war', 'more value per drop of water', 'recycling/reuse of water', 'water security', etc. (Pandey et al.,2011). However, freshwater availability is drastically changing worldwide due to natural variability and direct or indirect impact of human activities (Kummu et al., 2016; Rodell et al., 2018; Koutroulis et al., 2019). Current water resource planning and management do not address the effects of climate variability (White, 2006).Nevertheless, vulnerability to the climate change is one of the most crucial concerns of developing countries, and it is a critical element in the planning of any long-term development strategy (Beg et al., 2002).

Drawing upon the broader vulnerability literature (Kelly and Adger, 2000; Luers, 2005), vulnerability in the context of water resources refers to the susceptibility of a system (individual, community, place) to damage as a function of exposure to external forces (shocks, stress, disturbances), sensitivity of the system, and the ability of the system to respond (cope, recover, adapt). In this article, exposure, sensitivity and adaptive capacity are considered the three aspects of vulnerability. Based on the definitions provided by several authors (Watson \& Albritton 2001; Gallopín, 2006; Stathatou et al., 2016), exposure, sensitivity and adaptive capacity can be defined as follows:

- Exposure: the nature, degree, duration and/or extent to which the system is in contact with, or subject to perturbations.

- Sensitivity: the degree to which a system can be modified or affected by a disturbance or set of disturbances.

- Adaptive capacity: the ability of a system to adjust to disturbances, to moderate potential damages, to take advantage of opportunities, or to cope with the consequences of transformations that occur.

Thus, vulnerability assessments are essential in a bid to respond to future climate risks, and the assessment process itself can help combat current climate risks (TU-CDES, 2016). It is a process of identifying, quantifying, and prioritizing (or ranking) the vulnerabilities in a system. The frequency and magnitude of extreme weather events and disasters are increasing; and the developing countries are vulnerable to extremes of climatic variability and climate change (Turner et al., 2003). Coincidentally, increasing vulnerability in different spheres of life - social, physical, human, financial, and natural - increases people's susceptibility (Sarker et al., 2019; Rai et al., 2020).Rural communities in hills of Nepal are experiencing the impact of climate change on spring 
water resource (Chhetri and Adhikari, 2018).Water scarcities have multiple impacts on the living condition of people in these areas (Ghimire and Aryal, 2013). Water scarcity is now becoming an emerging global issue especially related to food and energy insecurity and impeding the gross domestic product (Panthi et al., 2018; Gurung et al., 2019). Dwindling water availability is the key issue impacting local livelihoods in the hills of Nepal (Bhatta, 2015; Chhetri et al., 2020). Furthermore, in scenario of water scarcity, the vulnerability of communities, especially at rural settings of mountainous regions, is the least analyzed (Pandey et al., 2014). Against this backdrop, this study has been carried out to assess spring water availability in rural areas, and how they face, fight back, and cope with the impact of climate change in the hills.

\section{Methodology}

\section{Study Site}

Gulmi, a hilly district in five number province of Nepal is composed of 10 rural municipalities. The study was carried out at the sub-district level in Ruru rural municipality (see Figure 1) covering an area of $67.38 \mathrm{~km}^{2}$ and population of 18,581. It consists of 6 wards including more than 54 small villages. It is the major catchment area of Gandaki river basin. The population of Ruru rural municipality has $48 \%$ males and $52 \%$ females. The main sources of economic activities include agriculture, livestock farming, tourism and foreign remittance. Chhetri et al. (2020) mention that reduced rainfall, landslide, flood, forest fire, etc. are the key threats causing scarce water resources in the district. The main characteristics of the study area consisting of 6 wards in Ruru rural municipality are illustrated in Table 1.

Table 1: Main characteristic of study area at ward level

\begin{tabular}{lllllll}
\hline $\begin{array}{l}\text { Ruru rural } \\
\text { municipality }\end{array}$ & Ruru & Gwadi & Thanpati & Baletaksar & Bamga & Reemuwa \\
\hline Wards & 1 & 2 & 3 & 4 & 5 & 6 \\
\hline Elevation (m) & $420-119$ & $438-1609$ & $676-1318$ & $750-1575$ & $552-1652$ & $447-1552$ \\
\hline Area (sq. km) & 11.57 & 14.48 & 8.01 & 12.57 & 12.57 & 8.39 \\
\hline Total population & 3306 & 2586 & 2585 & 4210 & 3475 & 2419 \\
\hline Population density & 285.83 & 178.53 & 322.61 & 335.02 & 276.44 & 288.24 \\
\hline
\end{tabular}

\section{Methods}

\section{Community Perception on Climate Change}

Participatory approach was adopted for understanding communities' perception on climate change and water availability. Structured questionnaires were administered. Data was gathered through survey, field observations and GPS recordings of coordinates of springs' locations, apart from current spring discharge. Focus group discussions (FGDs) were conducted followed by the questionnaire survey. The questionnaire was divided into three different sections:1) General information, 2) Vulnerability assessment, and 3) Checklist. The sample size of survey respondents was determined using Yamane's formulae (Singh and Masuku, 2014). Based on this formulae, more than 394 water consumers were invited to participate focused group discussion (FGD) who expressed their views on climate change and its impacts on water availability. 
The current discharge of the springs was measured by volumetric method (volume $\times$ time). Further, data of precipitation and temperature (minimum and maximum) was used from one of the nearest meteorological station. It helped understand trends of 30 years at micro level and compare the perception of climate change on water availability.

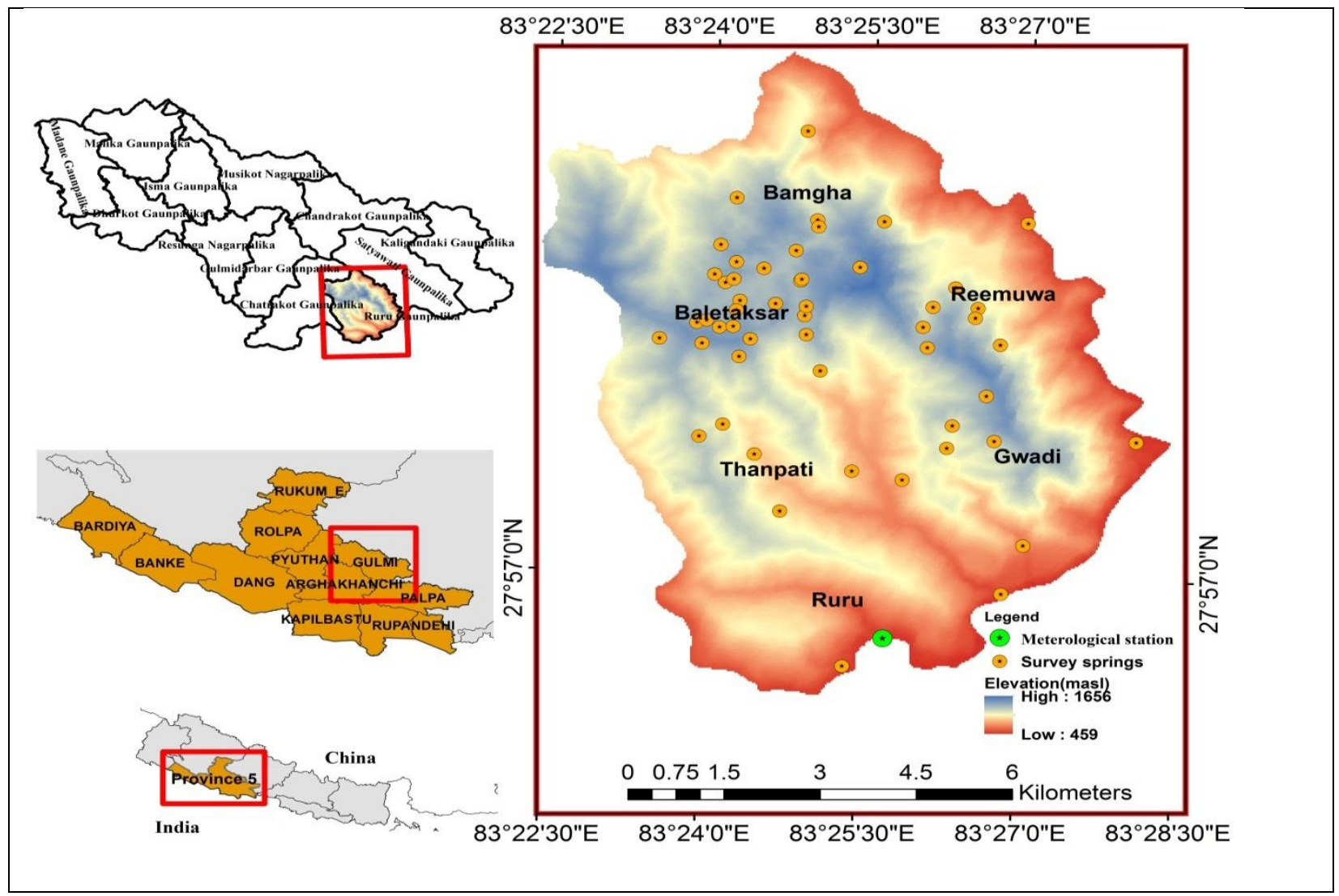

Figure 1: Map (Province, district, rural municipality, wards) of study area

\section{Vulnerability Assessment at Sub-District Level}

Participatory tools and methods were used for vulnerability assessment process. Three major indicators for the vulnerability assessment i.e. Exposure, Sensitivity, and Adaptive Capacity, were used. These three indicators were estimated using 11 sub-indices (Table 2). An exposure indicator reflects the demands of water, whereas the sensitivity indicator reflects the characteristic of the water availability. It is associated with exposures and stresses, and those indicators directly or indirectly affect the vulnerability of the water sector (Zhou, 2004). Similarly, the adaptive capacity deals with the bearing capacity of vulnerability.

\section{Data Analysis}

The data is analyzed in a way that the higher indicator values correspond to higher degree of exposure, sensitivity or adaptive capacity. These indicator values were further normalized as ratios of their respective thresholds. It offers an expected value ranging from 0 (non-vulnerable) to 1 (most vulnerable) for determining the availability of water in the study area. Finally, vulnerability index was calculated in accordance with the definition of IPCC (Intergovernmental Panel on Climate Change), i.e. as the ratio of the product of sensitivity and exposure index to the adaptive capacity 
index (Chhetri et al., 2018). The level of vulnerability was classified into four classes namely: 1) Low [0, 0.2], 2) Moderate [0.2, 0.4], 3) High [0.4, 0.7], and 4) Severe [0.7, 1] (Huang and Cai, 2009; Cai et al., 2016).

Table 2: Indicators of exposure, sensitivity and adaptive capacity of vulnerability assessment at sub-district level

\begin{tabular}{|c|c|c|c|}
\hline Index & $\begin{array}{c}\text { Index } \\
\text { Reflects }\end{array}$ & $\begin{array}{l}\text { Vulnerability } \\
\text { Class }\end{array}$ & $\begin{array}{l}\text { Measurement } \\
\text { Scale }\end{array}$ \\
\hline \multicolumn{4}{|l|}{ Exposure } \\
\hline Human population need & $\begin{array}{l}\text { Higher the water demand } \\
\text { increases }\end{array}$ & $+\mathrm{ve}$ & Ordinal \\
\hline Livestock population need & $\begin{array}{l}\text { Higher the water demand } \\
\text { increases }\end{array}$ & $+\mathrm{ve}$ & Ordinal \\
\hline \multicolumn{4}{|l|}{ Sensitivity } \\
\hline Population density & $\begin{array}{l}\text { Population pressure and } \\
\text { stress on a eco-system }\end{array}$ & $+\mathrm{ve}$ & Ordinal \\
\hline $\begin{array}{l}\text { Self-drinking water } \\
\text { accessibility }\end{array}$ & $\begin{array}{l}\text { Lower the water resource } \\
\text { number increases sensitivity }\end{array}$ & $+\mathrm{ve}$ & Ordinal \\
\hline Household Irrigation facility & $\begin{array}{l}\text { Water dependence of } \\
\text { agricultural production }\end{array}$ & $+\mathrm{ve}$ & Ordinal \\
\hline $\begin{array}{l}\text { Improved sanitation } \\
\text { accessibility }\end{array}$ & $\begin{array}{l}\text { Higher value means lower } \\
\text { access of sanitation }\end{array}$ & $+\mathrm{ve}$ & Ordinal \\
\hline $\begin{array}{l}\text { Household cultivated land } \\
\text { area percentage }\end{array}$ & $\begin{array}{l}\text { Water dependence of } \\
\text { agricultural production }\end{array}$ & +ve & Percentage \\
\hline \multicolumn{4}{|l|}{ Adaptive capacity } \\
\hline Literacy percentage & $\begin{array}{l}\text { Higher the literacy rate } \\
\text { provides the higher } \\
\text { awareness of water } \\
\text { management }\end{array}$ & $+\mathrm{ve}$ & Percentage \\
\hline $\begin{array}{l}\text { Percentage household } \\
\text { sufficient food production }\end{array}$ & $\begin{array}{l}\text { Higher the capacity higher } \\
\text { the resilience }\end{array}$ & $+\mathrm{ve}$ & $\begin{array}{l}\text { Percentage } \\
\text { Number (in } \\
\text { months) }\end{array}$ \\
\hline $\begin{array}{l}\text { Level of storage } \\
\text { capacity(Rainwater collection } \\
\text { tanks) }\end{array}$ & $\begin{array}{l}\text { Higher the storage capacity } \\
\text { of water }\end{array}$ & $+\mathrm{ve}$ & Percentage \\
\hline $\begin{array}{l}\text { Improved sanitation } \\
\text { accessibility }\end{array}$ & $\begin{array}{l}\text { Higher value means lower } \\
\text { access of sanitation } \\
\text { accessibility }\end{array}$ & $+\mathrm{ve}$ & Ordinal \\
\hline
\end{tabular}

\section{Results}

The findings of the research are shown into two sub-sections like the first sub-section deals with community perception on climate change and second sub-section represents vulnerability assessment. 
Doi: https://doi.org/10.33002/nr2581.6853.03031

\section{Community Perception on Climate Change}

Perception of respondents at all sites (six wards) and their responses are presented in Table 3. Majority of water consumer communities (more than 95\%) responded that they have an experience about the long-term weather changes with respect to temperature, rainfall pattern, rainfall intensity, occurrence of erratic rainfall and low rainfall, respectively. Communities have perceived the changes in rainfall intensity, timing of rainfall, and rainfall days as major problems. The discussion reckons that crisis of water resources is due to declining rainfall magnitude, decreasing rainfall days and shortening of duration of the rainy season. Local people lamented that they faced longer drought period leading to drying up and depletion of water spring sources, which ultimately affected traditional ponds and local water mills in the area.

Moreover, $90 \%$ respondents claimed that temperatures have been rising resulting into an increase in crop and livestock diseases and surged up drought occurrence. To adapt to climate induced problems such as drought, low and erratic rainfall, the water consumer communities have changed their cropping cycle. Although no flood risk was observed during the study, half of the respondents perceived landslide, soil erosion and flashflood may be due to the outcome of erratic and high intensity rainfall. Similarly, group interviews indicated that number of invasive plants (such as Ageratina adenophora, Lantana camara and Ageratum spp.) were increasing, and among them Ageratina adenophora was most dominant and has high dispersal rate in all the studied spring sites. A changing pattern in the plant phenology, especially in flowering period, was also observed in Rhododendron spp., Bauhania spp. and Mirabelle plum. Overall, majority of water consumer communities had common perception of changing climate.

Table 3: Water consumer communities' average perception on impacts of climate change from different study sites

\begin{tabular}{lllll}
\hline Indicators & Responses $(\%)$ & & \\
\hline & Increase & Decrease & No change & Don't know \\
\hline Over rainfall & 0 & 98 & 2 & 0 \\
\hline Low rainfall & 99 & 0 & 1 & 5 \\
\hline Temperature & 95 & 0 & 0 & 5 \\
\hline Drought duration & 93 & 0 & 0 & 7 \\
\hline Snow fall/hailstorm/Strong wind & 48 & 38 & 0 & 14 \\
\hline Erratic rainfall & 90 & 0 & 2 & 8 \\
\hline Changes in the rainfall intensity & 82 & 5 & 3 & 10 \\
\hline Winter are colder & 51 & 49 & 0 & 0 \\
\hline Summer are hotter & 49 & 46 & 5 & 0 \\
\hline Number of rainy days & 0 & 93 & 4 & 7 \\
\hline Flood & 1 & 99 & 0 & 10 \\
\hline Landslide/soil erosion/flashflood & 50 & 18 & 20 & 12 \\
\hline Forest fire & 53 & 37 & 9 & 1 \\
\hline Invasive species & 74 & 5 & 1 & 20 \\
\hline
\end{tabular}


Doi: https://doi.org/10.33002/nr2581.6853.03031

\begin{tabular}{lllll}
\hline Spring number & 0 & 98 & 1 & 2 \\
\hline Spring discharge & 0 & 95 & 2 & 3 \\
\hline Local water mills & 0 & 98 & 2 & 0 \\
\hline Traditional ponds & 0 & 98 & 0 & 2 \\
\hline Change in cropping cycle & 55 & 10 & 5 & 30 \\
\hline Crop diseases & 64 & 34 & 0 & 6 \\
\hline Change in plant phenology & 80 & 0 & 20 & 0 \\
\hline Introduced of hybrids livestock/plant species & 44 & 0 & 34 & 22 \\
\hline Reduction in crop production due to drought & 94 & 0 & 1 & 5 \\
\hline New diseases in crops/livestock & 64 & 30 & 2 & 4 \\
\hline
\end{tabular}

During the FGD and timeline analysis, respondents expressed that they had experienced and observed increased climatic risks and hazards. According to their responses, erratic rainfall and drought has resulted in drying up of water resources, which was the topmost hazard ranked in the study area (Figure 2). This ranking of hazard was followed by flashflood, soil erosion, invasive species, hailstorms/ strong wind and forest fires (Figure 2).

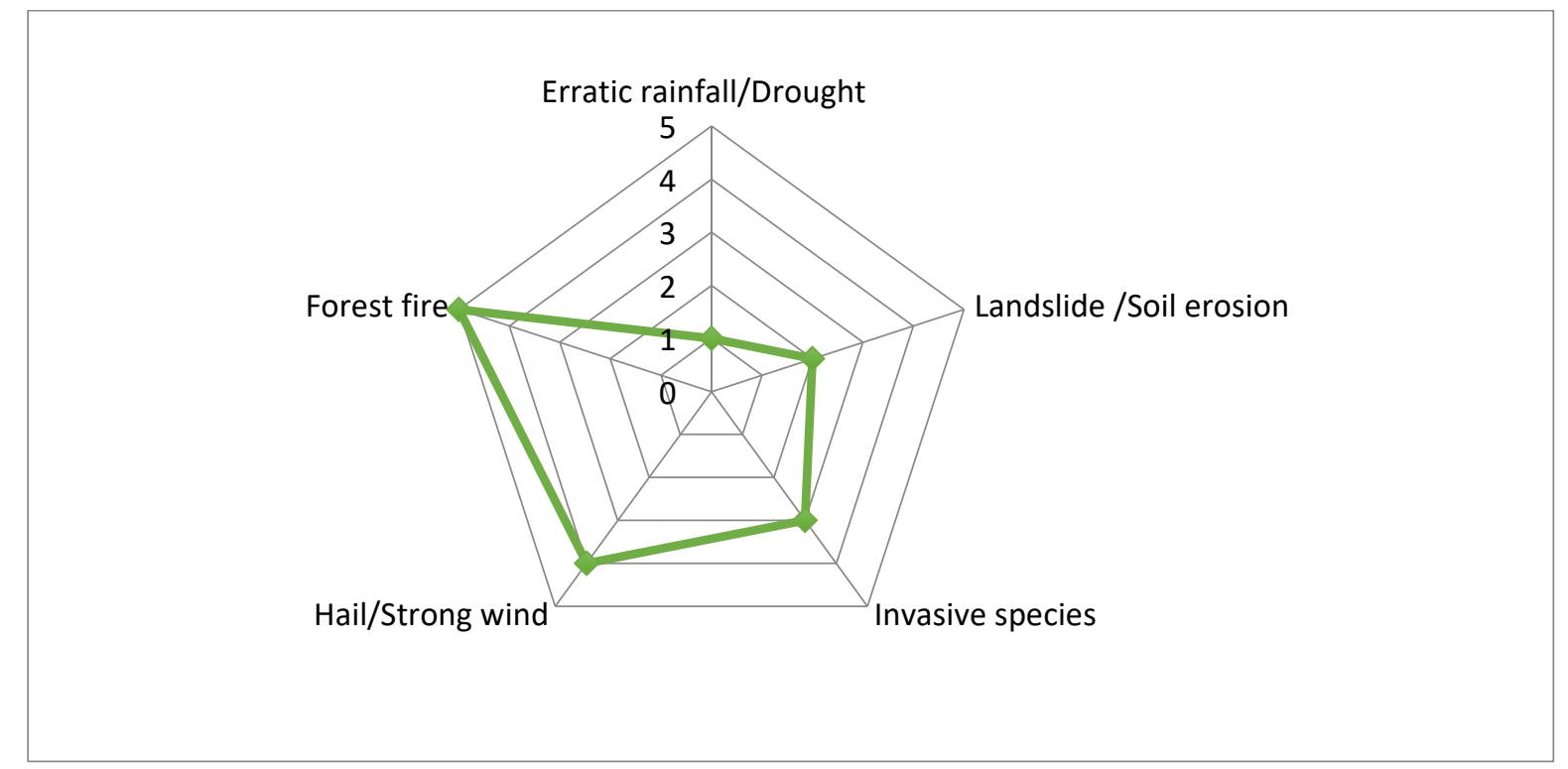

Figure 1: Radar diagram on climate hazards/risks

\section{Spring Discharge Measurement}

The bar graph in Figure 3 illustrates the current spring discharge measurements taken during field study. More than 90 percent of peoples in the area were dependent on the spring sources for primary water consumption. Survey of 54 perennial springs was done in Ruru rural municipality from December 2018 to January 2019 (Figure 1). Discharge of 10 perennial springs was measured.

The discharge results were found correlating with past trends. Average spring discharge in 10 springs shows the rate of 0.58 liter/second. According to water consumer communities, more than 
75 percent of springs discharges decreased in last three decades. Despite vegetation cover around the water sources and springs has increased, the drying up of springs is increasing. Drying up of spring sources resulted in lesser water availability for drinking, livestock and irrigation. Many villages in the area suffer from severe water crisis during dry period. It is also noted that it takes 3 4 hours for fetching the water from far spring sources. Increased travel time revealed that climate change impacts are perceived by water consumer community especially drought has several impacts on springs water availability.

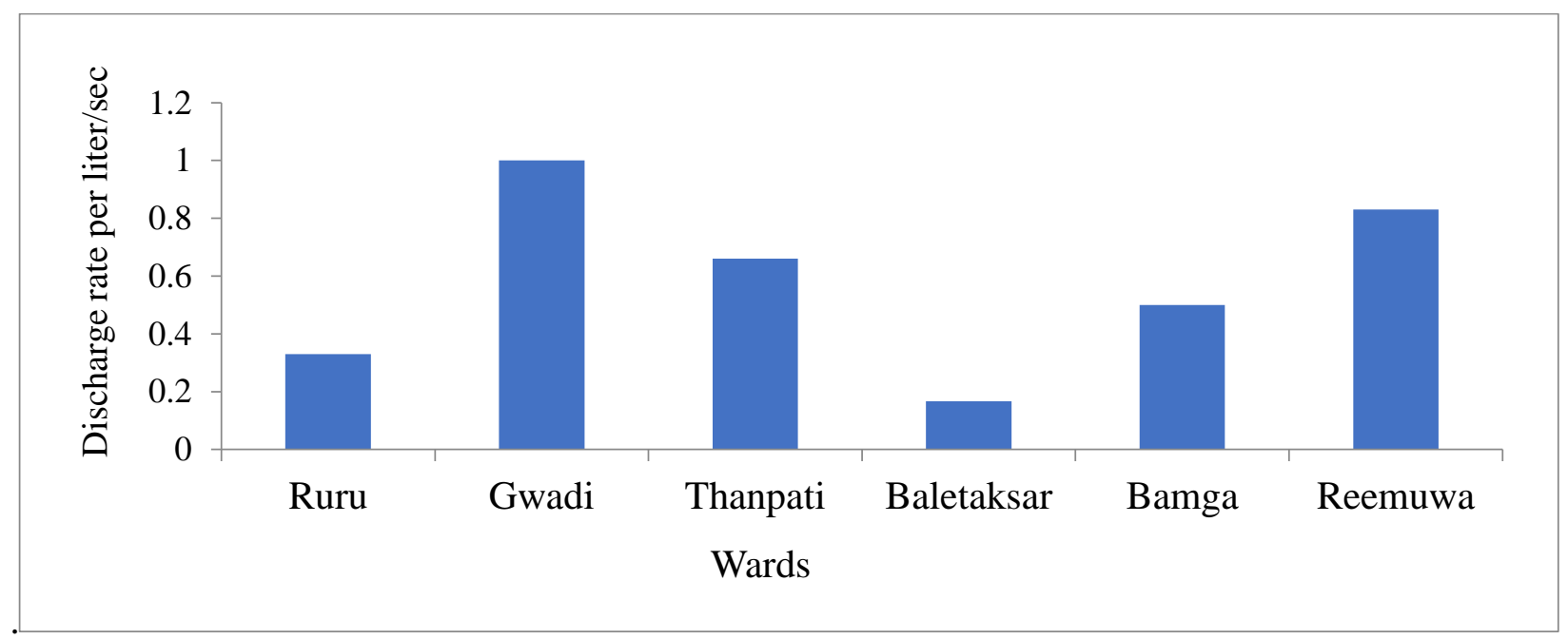

Figure 2: Wards showing spring discharge rate (liter/second)

\section{Meteorological Data Analysis}

The pattern of a rainfall and temperature data from 1987 to 2017 shows the variations significantly (Figure 4). The highest annual rainfall was recorded during $1998(2812.5 \mathrm{~mm})$ and lowest in 2004 $(1233.6 \mathrm{~mm})$. Likewise, the highest average temperature $\left(18.56^{\circ} \mathrm{C}\right)$ was observed during 2016 and lowest was in $1997\left(16.52^{\circ} \mathrm{C}\right)$. Additionally, annual and seasonal temperature and rainfall data were analyzed using the Mann-Kendall (Mann, 1945 and Kendall, 1975) and Sen's slope model (Sen, 1968), respectively. The Z values of Mann-Kendall and Sen's slope tests represent both positive and negative trends in the study area (Table 4). It has showed the decreasing trend (negative trends) in the pattern of annual rainfall, post-monsoon rainfall and winter rainfall, while pre-monsoon rainfall showed increasing trend. Over a period of 30 years, the trend of $Z$ values of Mann-Kendall and Sen's slope tests appears positive for the annual and seasonal rainfall at average temperature, maximum temperature and minimum temperature. The trend analysis has been done for annual rainfall and seasonal rainfall at the 5\% significance level $(p<0.05)$ and $10 \%$ significance level $(p<0.1)$, respectively. When the $p$ value is less than significance level, then the null hypothesis is rejected, which shows that there is a trend in the time series. When $p$ value is high the significance level accepting null hypothesis indicates that there is no trend. On rejecting the null hypothesis, the result is statistically significant.

Statistically significant trend was found in annual rainfall; however, there was no significant trend in seasonal rainfall. At the same time, statistically significant trend was also found in average temperature and maximum temperature. It also shows the significant trend in seasonal temperature 
Doi: https://doi.org/10.33002/nr2581.6853.03031

during pre-monsoon and winter periods, while minimum temperature was recorded in monsoon season.

\section{Vulnerability Assessment}

The vulnerability assessment in the wards of Ruru rural municipality was done by using three indicators, namely exposure, sensitivity and adaptive capacity. These three indicators were estimated by using sub-indices based on 11 indicators. Exposure of each ward at Ruru municipality was estimated by using livestock and human population demands and the value was ranged from 0.17 to 0.75 . The value of exposure index shows the highest at Reemuwa and lowest demand at Baletaksar (Table 4). While adaptive capacity of each ward at Ruru municipality was estimated by using four indicators. The estimated value ranged from 0.73 to 0.94 (Table 4). Highest adaptive capacity was found at Thanapati and lowest at Bamga. For obtaining the indicator value of sensitivity at ward level was determined by five indicators. Result of sensitivity index values ranged from 0.44 (lowest at Baletaksar) to 0.83 (highest at Gwadi) as shown in Table 4.Vulnerability index of water availability classification was based onfour classes as follows:1) low [0-0.2], 2) moderate [0.2-0.4], 3) high [0.4-0.7], and 4) severe [0.7-1.0] (Huang and Cai, 2009; Cai et al., 2016) (Table 5 and Figure 4). Finally, the study demonstrates that the degree of vulnerability of water availability varies from 0.10 (lowest at Baletaksar) to 0.67 (highest adaptive at Reemuwa).

Table 4: Value of exposure, sensitivity and adaptive capacity index of six wards

\begin{tabular}{lllllll}
\hline Wards & Ruru & Gwadi & Thanpati & Baletaksar & Bamga & Reemuwa \\
\hline Exposure & 0.67 & 0.67 & 0.58 & 0.17 & 0.67 & 0.75 \\
\hline Sensitivity & 0.59 & 0.83 & 0.59 & 0.44 & 0.66 & 0.78 \\
\hline Adaptive capacity & 0.93 & 0.89 & 0.94 & 0.75 & 0.73 & 0.87 \\
\hline
\end{tabular}

Table 5: Value of vulnerability index of water availability and ranks of six wards

\begin{tabular}{lllllll}
\hline Wards & Ruru & Gwadi & Thanpati & Baletaksar & Bamga & Reemuwa \\
\hline Vulnerability & 0.43 & 0.62 & 0.36 & 0.10 & 0.60 & 0.67 \\
\hline Rank of vulnerability & 4 & 2 & 5 & 6 & 3 & 1 \\
\hline Value Interpretation & High & High & Moderate & Low & High & High \\
\hline
\end{tabular}

\section{Discussion}

Perceptions of climate change were based on views, values and experiences of community living in their particular area. Water consumer communities have perceived the impacts of climate change. Focus group discussions revealed the climate variability across different variables (such as the water, forests and agricultural sectors). All stakeholders show that they have perceived changes in temperature and rainfall patterns. Low rainfall and erratic rainfall were responsible for the drought. Moreover, local perceptions of climate change gathered through the survey show the same trends drawn from the meteorological data. The results of this study are identical to the outcome of increasing trend in average temperature as witnessed by other investigations (PAN, 2009; Shrestha et al., 1999; Shrestha et al., 2019; Tiwari et al., 2010). The increment in occurrence of pests, diseases and invasive species is noticed. It conforms to previous studies done by 
Chaudhary and Bawa (2011), Macchi et al. (2014) and Uprety et al. (2017) basing the perceptions of climate change.

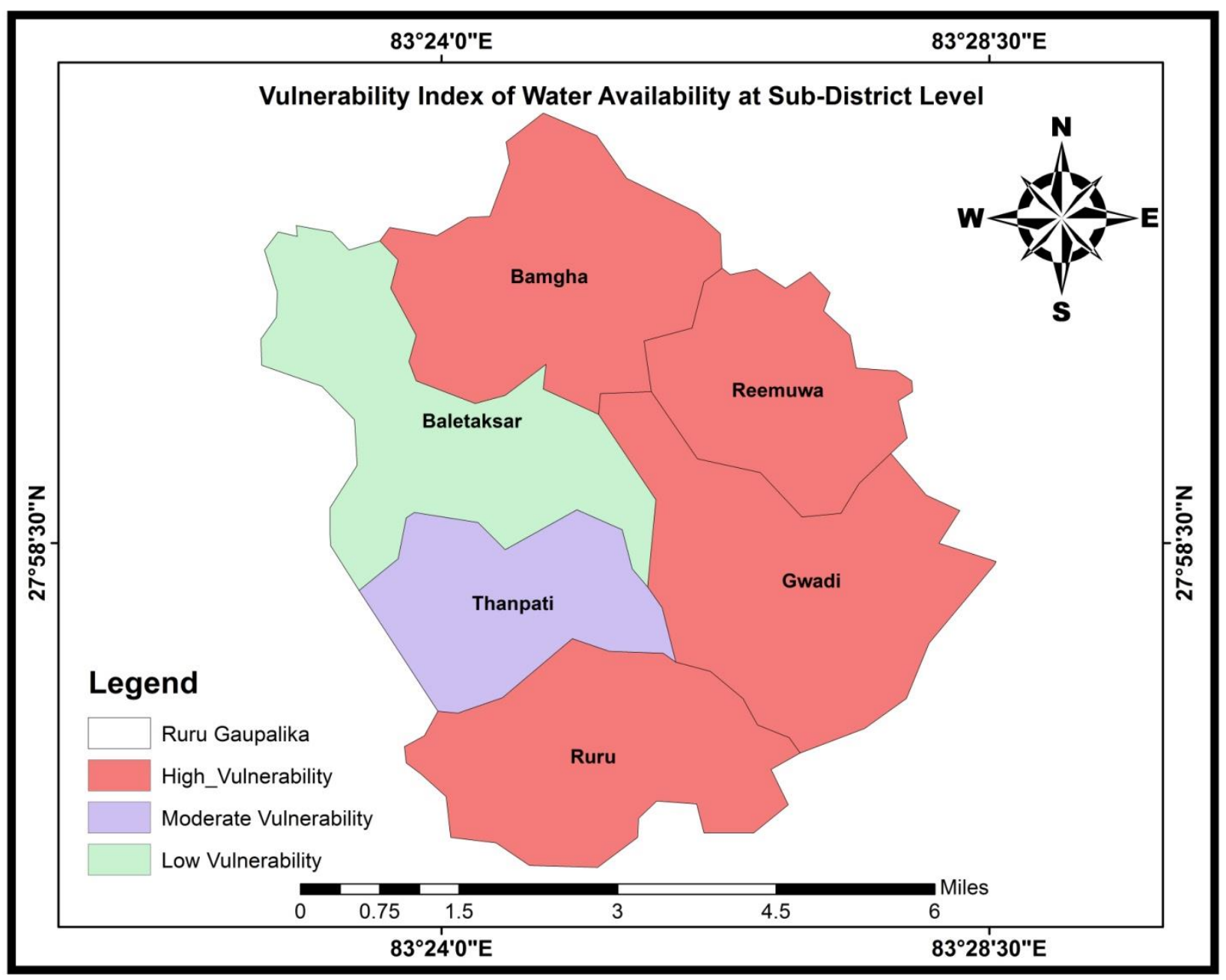

Figure 3: Map showing vulnerability index of water availability at sub-district level

For the responses regarding the quantity and timing of rainfall, $90 \%$ of the local respondents felt or found the rising trend of erratic rainfall and decline in rainfall pattern. Meteorological data of rainfall also shows the decreasing trend with inter-annual variations as reported earlier (Joshi et al., 2019; Piya et al., 2012). Occurrence of early flowering was observed in Rhododendronspp., Bauhania spp., Myrica esculenta, and Mirabelle plum, as noticed by water consumer communities. About $80 \%$ of the 13 million people living in the hilly and mountainous region of Nepal rely on springs as their primary source of water (Poudel and Duex, 2017). In the study area, water crisis occurred which was severe during dry periods. Average value of discharges of ten springs were taken and compared with other springs. In the view of water consumer communities, spring sources are drying up and decrease was noted in the discharge rate. This is positively correlated with the data of past two decades. It is challenging to get proper information and knowledge about climate change, which directly impacts the decision-making process at the local level. The uncertainty created by climate variability is already a key problem for the communities and it is must to be dealt with. It has strengthened the conclusion given by Silvestri et al. (2012). Further, Manandhar 
et al. (2015) pointed out that such information is useful for decision makers who need to understand and facilitate climate change and its related hazard management at a local level.

Meanwhile, the impact of climate change hampers local dwellers' livelihood and invites frequent disaster to their life (Sarker et al., 2020). In the future, these impacts will further increase; therefore, it is the urgent need to mitigate and adapt to climate change impacts. Thus, well understanding about these perceptions can help policymakers for supportive climate-related actions and policies. Further, the vulnerability studies were carried out to know the situation of water availability in different wards. The vulnerability assessment for water availability was performed using three main indicators with sub-indices, and it characterized vulnerabilities at sub-district levels (ward levels). Human and livestock demands were included as sub-indices of exposure parameters while sensitivity included cultivated land area percentage, irrigation facility percentage, self-drinking water accessibility and spring discharge rate. Meanwhile, literacy percentage, household food production, accessibility to improved sanitation and rainwater collection tanks were included in adaptive capacity index at ward level. Finally, vulnerability of water availability at ward level was explored by using the 11indices.Vulnerability index (VI)values ranged from 0.10 to 0.67.Vulnerability index of water availability at ward level shows high vulnerability in four wards, moderate in Thanpati and low in the Baletaksar, based on the classification of Huang and Cai (2009). About $80 \%$ of rural people were dependent on the agriculture in this area. Reduced water availability has several effects on crop production, human health and food security. The primary cause of the water vulnerability is the high dependency of rural people on agriculture (Pandey, 2015; Chhetri et al., 2020). Community with low adaptive capacity and poor infrastructure further aggravate the vulnerability of these areas. They are highly dependent on government and other organization for the development plans. Likewise, the study conducted by Chhetri et al. (2018) and Chhetri and Adhikari (2018) also found that the increased vulnerability of the water resources was due to the low adaptive capacity. Through the way of spring water vulnerability analysis, great insight was achieved concerning the water availability situation which highlights the vulnerability profiles of wards. The proposed methodology can be a tool for identification of better solutions to water management-decision problems and/or can provide important insights during decision making in similar environments (Simha et al., 2017).

\section{Conclusion}

The main purpose of this study was to assess the vulnerability of diminishing spring water resources and to understand local peoples' perceptions at the mid-hill wards of rural areas. More than 394 people took part in the focus group discussions. Perceptions of climate change based on views, experiences of community and climatic data of long-term rainfall and temperature (1987 to 2017). It has been found that the majority of water consumer communities have an experience of changes in pattern of the local climate and environment. By comparing the climatic observation and correlating the public perceptions, this study reveals the change in rainfall, temperature and drought pattern. Overall, most of the wards were vulnerable to impacts of climate change due to increase in temperature, less or more erratic precipitation, drought, decrease of spring water availability, increase in invasive species, crop diseases and forest fires. Furthermore, for the spring water availability in wards, vulnerability index was found ranging between 0.10 to 0.67 . Vulnerability profiles of water availability at wards level show high vulnerability in four wards, moderate in Thanpati and low in the Baletaksar. Finally, the outcomes of this study offer a clear 
vision on identifying tasks for risk-mitigation, planning and management strategies that ultimately can support local communities to improve their livelihood sustainably.

\section{Acknowledgment}

The authors would acknowledge the Kali Gandaki Polytechnic Institute, CTEVT, Nepal for supporting this study and lab facilities. The authors would also like thanks to the educational head Mr. Gobinda Paudel for his concern support and kind cooperation during the study period.

\section{References}

Alcamo, J., Moreno, J.M., Nováky, B., Bindi, M., Corobov, R., Devoy, R., Giannakopoulos, C., and Araujo, M. (2007). Europe. Climate Change 2007: Impacts, Adaptation and Vulnerability: Contribution of Working Group II to the Fourth Assessment Report of the Intergovernmental Panel on Climate Change. In IPCC WGII Fourth Assessment Report (pp. 541-580). Cambridge: Cambridge University Press.

Al-Kalbani, M., Price, M., Abahussain, A., Ahmed, M., and O'Higgins, T. (2014). Vulnerability assessment of environmental and climate change impacts on water resources in Al Jabal Al Akhdar, Sultanate of Oman. Water, 6(10): 3118-3135.

Beg, N., Morlot, J. C., Davidson, O., Afrane-Okesse, Y., Tyani, L., Denton, F., \& Parikh, K. (2002). Linkages between climate change and sustainable development. Climate Policy, 2(2-3): 129144.

Bhatta, L.D., van Oort, B.E.H., Stork, N.E. and Baral, H. (2015). Ecosystem services and livelihoods in a changing climate: Understanding local adaptations in the Upper Koshi, Nepal. International Journal of Biodiversity Science, Ecosystem Services \& Management, 11(2): 145-155.

Cai, J., Yin, H., and Varis, O. (2016). Impacts of industrial transition on water use intensity and energy-related carbon intensity in China: A spatio-temporal analysis during 20032012. Applied Energy, 183: 1112-1122.

Chaulagain, N.P. (2009). Impacts of climate change on water resources of Nepal: The physical and socio-economic dimensions. In IOP Conference Series: Earth and Environmental Science, 6(29): 292029.

Chen, Y., Feng, Y., Zhang, F., and Wang, L. (2019). Assessing Water Resources Vulnerability by Using a Rough Set Cloud Model: A Case Study of the Huai River Basin, China. Entropy, 21(1):14.

Chhetri, R. and Adhikari, S. (2018). The Impacts of Climate Change on water resources in Hilly Areas of Nepal. I-Manager's Journal on Future Engineering and Technology, 13(3):42-49.

Chhetri, R. and Kumar, P. (2018). Spatial and Temporal variability of rainfall distribution in hilly region of Nepal. International Research Journal of Environmental Sciences, 7 (11): 1-10.

Chhetri, R., Kumar, P., Pandey, V.P., Singh, R. and Pandey, S. (2020). Vulnerability assessment of water resources in Hilly Region of Nepal. Sustainable water Resources Management, 2020(6):34.

Chhetri, R., Ganguly, S., Chand, H.B., Adhikari, S., Raut, R. and Sharma, B. (2018). Vulnerability Assessment of Climate Change Impacts on Water Resources at Community Level in Hilly areas of Nepal. Journal of Energy Research and Environmental Technology (JERET), 5(2): $30-34$. 
Chowdhury, R. and Beecham, S. (2010). Australian rainfall trends and their relation to the southern oscillation index. Hydrological Processes, 24(4): 504-514.

Gallopín, G.C. (2006). Linkages between vulnerability, resilience, and adaptive capacity. Global Environmental Change, 16(3): 293-303.

Ghimire, N.P. and Aryal, M. (2013). Analysis of Perception and Adaptation to Climate Change by Farmers in Gulmi District, Nepal. Journal of Agriculture and Environment, 14: 31-43.

Gurung, A., Adhikari, S., Chauhan, R., Thakuri, S., Nakarmi, S., Ghale, S., Dongol, B.S., and Rijal, D. (2019). Water crises in water-rich country: case studies from rural watersheds of Nepal's mid-hills. Water Policy, 1-22.

Hamouda, M.A., El-Din, M.M.N. and Moursy, F.I. (2009). Vulnerability assessment of water resources systems in the Eastern Nile Basin. Water Resources Management, 23(13): 26972725.

Huang, Y. and Cai, M. (2009). Methodologies guidelines: Vulnerability assessment of freshwater resources to environmental change. United Nations Environment Programme (UNEP) \& Peking University, China in collaboration with Mongolian Water Authority and Asian Institute of Technology (AIT), Khlong Nueng.

Javan, K., Azizzadeh, M.R. and Yousefi, S. (2016). An Investigation and assessment of meteorological drought in Lake Urmia Basin using drought indices and probabilistic methods. Natural Environment Change, 2(2):153-164.

Joshi, A., Farquhar, S., Assareh, N., Dahlet, L., and Landahl, E. (2019). Climate change in Lamjung District, Nepal: meteorological evidence, community perceptions, and responses. Environmental Research Communications, 1:1-13.

Kelly, P.M., and Adger, W.N. (2000). Theory and practice in assessing vulnerability to climate change and Facilitating adaptation. Climatic Change, 47(4):325-352.

Kendall, M.G., 1975. Rank correlation methods. London: Charles Griffin.

Komba, C. and Muchapondwa, E. (2018). Adaptation to climate change by smallholder farmers in Tanzania.In Agricultural Adaptation to Climate Change in Africa. ROUTLEDGE in association with GSE Research, 29(168): 129-168.

Koutroulis, A.G., Papadimitriou, L.V., Grillakis, M.G., Tsanis, I.K., Warren, R., and Betts, R.A. (2019). Global water availability under high-end climate change: A vulnerability-based assessment. Global and Planetary Change, 175: 52-63.

Kummu, M., Guillaume, J. H.A., Demoel, H., Eisner, S., Flörke, Porkka, M., Florke, M., Siebert, S., Veldkamp, T.I.E and Ward, P.J. (2016). The world's road to water scarcity: Shortage and stress in the 20th century and pathways towards sustainability'. Sci. Rep., 6(38495): 1-16.

Kundzewicz, Z.W., Mata, L.J., Arnell, N.W., Doll, P., Kabat, P., Jimenez, B., Miller, K., Oki, T., Zekai, S., and Shiklomanov, I. (2007). Freshwater resources and their management. In: Parry, M. L., Canziani, O. F., Palutikof, J. P., van der Linden, P. J. and Hanson, C. E. (eds.), Climate Change 2007: Impacts, Adaptation and Vulnerability. Contribution of Working Group II to the Fourth Assessment Report of the Intergovernmental Panel on Climate Change. Cambridge University Press, pp. 173-210. ISBN 9780521880091 173-210.

Luers, A.L. (2005). The surface of vulnerability: an analytical framework for examining environmental change. Global Environmental Change, 15(3): 214-223.

Macchi, M., Gurung, A.M., and Hoermann, B. (2014). Community perceptions and responses to climate variability and change in the Himalayas. Climate and Development, 7(5): 414-425.

Magesa, B.A., and Pauline, N.M. (2019). Responses of water insecure coastal communities of Tanzania to climate change impacts. Is it incremental or transformative adaptation? Climate and Development, 1-10. 
Doi: https://doi.org/10.33002/nr2581.6853.03031

Mann, H.B. (1945). Nonparametric tests against trend. Econometrica, 13: 245-259.

Manandhar, S., Pratoomchai, W., Ono, K., Kazama, S. and Komori, D. (2015). Local people's perceptions of climate change and related hazards in mountainous areas of northern Thailand. International Journal of Disaster Risk Reduction, 11: 47-59.

MOF (2017). Economic Survey: Fiscal Year 2016/17. Government of Nepal, Ministry of Finance, Singh Durbar, Kathmandu, Nepal.

PAN (2009). Temporal and Spatial Variability of Climate Change over Nepal (1976-2005). Practical Action Nepal, Kathmandu.

Pandey, R., Kala, S. and Pandey, V.P. (2015). Assessing climate change vulnerability of water at household level. Mitigation and Adaptation Strategies for Global Change, 20(8), 1471-1485.

Panthi, J., Khatiwada, K.R., Shrestha, M.L. and Dahal, P. (2018). Water poverty in the context of climate change: a case study from Karnali river basin in Nepal Himalaya. International Journal of River Basin Management, 1-8.

Piya, L., Maharjan, K. L. and Joshi, N.P. (2012). Perceptions and realities of climate change among the Chepang communities in rural mid-hills of Nepal. Journal of Contemporary India Studies: Space and Society, 2: 35-50.

Poudel, D.D. and Duex, T.W. (2017). Vanishing springs in Nepalese mountains: Assessment of water sources, farmers' perceptions, and climate change adaptation. Mountain Research and Development, 37(1), 35-46.

Rai, C. M., Chhetri, R., Dahal, B.P., and Adhikari, S. (2020). Analysis of rainfall and return periods to assess flood risks in hilly areas of Nepal. International Research Journal of Environmental Sciences, 9(3):7-14.

Raneesh, K.Y. (2014). Impact of climate change on water resources. Journal of Earth Science \& Climatic Change, 5(3):1.

Rodell, M., Famiglietti, J.S., Wiese, D.N., Reager, J.T., Beaudoing, H.K., Landerer, F.W. and Lo, M.H. (2018). Emerging trends in global freshwater availability. Nature, 557(7707): 651.

Salem, A.B., Salem, S.B., Kahime, K., Messouli, M., and Khebiza, M.Y. (2019). Vulnerability of Human Populations to Climate Change: Focus on Socio-Economical Factors. In Handbook of Research on Global Environmental Changes and Human Health (pp. 22-40).

Sarker, M.N.I., Wu, M., Alam, G.0M. and Shouse, R.C. (2019). Livelihood vulnerability of riverine-island dwellers in the face of natural disasters in Bangladesh. Sustainability, 11(6), 1623.

Sarker, M.N.I., Wu, M., Alam, G.M. and Shouse, R.C. (2020). Life in riverine islands in Bangladesh: Local adaptation strategies of climate vulnerable riverine island dwellers for livelihood resilience. Land Use Policy, 94: 104574.

Sarma, R., and Singh, D.K. (2019). Spatio-temporal analysis of drought and aridity in Gomtibas. CURRENT SCIENCE, 116(6): 919-925.

Sen, P.K. (1968). Estimates of the regression coefficient based on Kendall's tau. Journal of the American Statistical Association, 63(324): 1379-1389.

Shrestha, A.B., Wake, C.P., Mayewski, P.A., and Dibb, J.E. (1999). Maximum temperature trends in the Himalaya and its vicinity: an analysis based on temperature records from Nepal for the period 1971-94. Journal of Climate, 12(9): 2775-2786.

Shrestha, R.P., Pasakhala, B. and Qasim, S. (2019). Assessing Household Vulnerability to Climate Variability in Far-West Nepal. Journal of Sustainable Development Studies, 12(2):83-118.

Silvestri, S., Bryan, E., Ringler, C., Herrero, M. and Okoba, B. (2012). Climate change perception and adaptation of agro-pastoral communities in Kenya. Regional Environmental Change, 12(4): 791-802. 
Simha, P., Mutiara, Z.Z., and Gaganis, P. (2017). Vulnerability assessment of water resources and adaptive management approach for Lesvos Island, Greece. Sustainable Water Resources Management, 3(3): 283-295.

Singh, A.S. and Masuku, M.B. (2014). Sampling techniques \& determination of sample size in applied statistics research: An overview. International Journal of Economics, Commerce and Management, 2(11): 1-22.

Stathatou, P.M., Kampragou, E., Grigoropoulou, H., Assimacopoulos, D., Karavitis, C., Porto, M. F.A., Gironas, J., Vanegas, M. and Reyna, S. (2016). Vulnerability of water systems: a comprehensive framework for its assessment and identification of adaptation strategies. Desalination and Water Treatment, 57(5): 2243-2255.

Tiwari, K.R., Awasthi, K.D., Balla, M.K. and Sitaula, B.K. (2010). Local people's perception on climate change, its impact and adaptation practices in Himalaya to Terai regions of Nepal. Himalayan Research Papers Archive. http://www.forestrynepal.org/publications/article/4837.

TU-CDES (2016). Vulnerability Impact Assessment of Climate Change Impact in Mountain Ecosystems: A Practical Guideline. Central Department of Environmental Science, Tribhuvan University and Ministry of Forests and Soil Conservation, Kathmandu.

Turner, B.L., Kasperson, R.E., Matson, P.A., McCarthy, J.J., Corell, R.W., Christensen, L., Eckley, N., Kasperson, J.X., Luers, A., Martello, M.L., Polsky, C. and Pulsipher, A. (2003). A framework for vulnerability analysis in sustainability science. Proceedings of the National Academy of Sciences, 100(14): 8074-8079.

Uprety, Y., Shrestha, U.B., Rokaya, M.B., Shrestha, S., Chaudhary, R.P., Thakali, A. and Asselin, H. (2017). Perceptions of climate change by highland communities in the Nepal Himalaya. Climate and Development, 9(7): 649-661.

Watson, R.T. and Albritton, D.L. (Eds.). (2001). Climate change 2001: Synthesis report: Third assessment report of the Intergovernmental Panel on Climate Change. Cambridge University Press.

White, K.D., Vaddey, S.V., Hamlet, A.F., Cohen, S.J., Neilsen, D., Taylor, W. (2006). Integrating climate impacts in water resource planning and management. In M. Davies (ed.) and J.E. Zurfelt, Proceedings of the 13th International Conference on Cold Regions Engineering, Current Practices in Cold Regions Engineering, Orono, Maine, July 23-26, 2006, Reston, Virginia: American Society of Civil Engineering.

Wondimagegn, T., and Lemma, S. (2016). Climate change perception and choice of adaptation strategies: Empirical evidence from smallholder farmers in east Ethiopia. International Journal of Climate Change Strategies and Management, 8(2): 253-270.

Zhou, Y. (2004). Vulnerability and adaptation to climate change in North China: the water sector in Tianjin. Hamburg University and Centre for Marine and Atmosphere Science, Research Unit Sustainability and Global Change, Hamburg, Germany. 